\title{
The cost of making compensation payments to local forest populations in a REDD+ pilot project in Madagascar
}

\author{
Laura Brimontl, Driss Ezzine-de-Blas"l and Alain \\ Karsenty"
}

\author{
Correspondence: \\ Laura Brimont \\ International Institute for Sustainable Development and \\ International Relations (IDDRI) \\ 41 Rue du Four \\ 75006 Paris \\ Email: laura.brimont@sciencespo.fr
}

\begin{abstract}
REDD+ is usually presented as an incentive-based mechanism that can provide payments to compensate for the costs induced by conservation restrictions. Yet in Madagascar REDD+ is implemented through a command-and-control approach with almost no or insufficient compensation. This paper challenges the financial feasibility of an individual cash or in-kind compensation scheme as part of a REDD+ project and assesses the cost of implementing a hypothetical individual compensation scheme for local populations living on the boundary of an ongoing REDD+ pilot project in southeastern Madagascar. In order to estimate a plausible level of compensation, we measured households' perceived economic losses arising from the project. We carried out this economic evaluation based on households' declarative statements about their agricultural production (before and after project implementation) and their perceptions of the causes of such changes. We then estimated the start-up and running costs of implementing conditional transfers to compensate for reported losses using first-hand project cost data from different conservation projects in Madagascar, including the one analysed in this paper. Comparing our estimated total cost to the current budget of the REDD+ project, we concluded that compensating households would cost seven times more than the budget initially devoted to field activities during the first phase of the project. Yet we discuss that individual compensation may increase the long-term environmental and social additionality (through greater legitimacy) of the REDD+ project, as it may play a role of safety nets and help farmers, especially the most vulnerable ones, to implement new agricultural techniques to adapt to land use restrictions.
\end{abstract}

\section{RÉSUMÉ}

REDD+ est généralement présenté comme un mécanisme incitatif basé sur la compensation des coûts induits par les mesures de conservation de la forêt. Cette vision de REDD+ tend toutefois à être remise en cause par la réalité des projets pilotes. À Madagascar par exemple, les projets pilotes sont mis en œuvre selon une logique contraignante voire coercitive, où les compensations pour les populations locales sont extrêmement réduites. Partant de l'hypothèse que I'un des facteurs explicatifs de l'absence de mécanisme de compensation directe est un coût trop élevé, ce papier évalue le coût de la mise en œuvre d'un système de compensations monétaires individuelles en parallèle des activités de conservation et de développement d'un projet pilote REDD+ situé au sud-est de Madagascar. Pour ce faire, nous estimons les pertes économiques induites par le projet telles que perçues par les ménages au moyen d'entretiens individuels. Ces entretiens nous ont permis de reconstituer la production des ménages avant et après la mise en œuvre du projet, et d'évaluer dans quelle mesure les changements opérés étaient ou non dus à l'implémentation du projet REDD+. Dans un second temps, nous estimons les coûts de transaction liés à la mise en œuvre du système de compensation en utilisant des données issues de différents projets de conservation et de développement à Madagascar. La confrontation de nos estimations avec le budget actuel du projet REDD+ montre que compenser les pertes individuelles des mé- nages est hors de la portée financière du projet, puisque cela représente sept fois le budget dédié aux activités de développement local pendant la première phase du projet. Dans la discussion, nous revenons sur l'intérêt d'associer des compensations individuelles aux programmes d'investissement agricole, dans la mesure où les compensations jouent un rôle de " filet de sécurité » pour les ménages, notamment les plus vulnérables, et les encouragent à expérimenter de nouvelles techniques agricoles leur permettant de s'adapter aux restrictions d'usage.

\section{INTRODUCTION}

Tropical forests play a major role in climate regulation, both for the regulation of hydrological and carbon cycles (IPCC 2007, Pan et al. 
2011) and as hosts of invaluable biological diversity ( $O^{\prime}$ Connor 2008). The Reduction of Emissions from Deforestation and Degradation (REDD+) is an international initiative which seeks to channel funds with the support of the UNFCCC (United Nations Framework Convention on Climate Change) negotiations to encourage tropical countries to protect their forests. Socio-economic incentives and performance-based payments are one of the core principles of REDD+ (Karsenty and Ongolo 2012), which explains why the implementation of some REDD+ projects contains payments for environmental services as a separate but complementary tool (Ezzine-de-Blas et al. 2015). Madagascar has a record of implementing REDD+ strategies through command-and-control approaches using protected areas with almost no or insufficient compensation (Brimont and Karsenty 2015). In Madagascar, there are currently four ongoing REDD+ pilot projects being implemented by international environmental NGOs. All of them plan to create new protected areas, following the line of the pre-REDD+ national conservation strategy; in 2003, the Government of Madagascar decided to more than triple the size of the protected areas network (Corson 2011), which is planned to cover $40 \%$ of the remaining natural forest of the island (S. Desbureaux 2014, pers. comm.). When protected areas fall in populated areas within or along its boundary, the NGOs have traditionally supported the creation of management transfer contracts (transferts de gestion) from the state to the communities. The community-represented by an ad hoc legally recognized local institution called VOI (Vondron'Olona Ifotony) -is required to respect and enforce a management plan which defines zones with different degrees of protection-and therefore land use rights-depending on the type of land use found at the time of the management transfer. For example, forests in the buffer area of the protected area are usually classified as strict conservation zones. In the other zones, further from the edge of the protected area and where forests are more degraded, harvesting activities for timber and non-timber products are allowed through strict regulations enforced by the $\mathrm{VOI}$ and the protected area management organization
(Madagascar National Parks, MNP), which oblige households to pay a harvesting fee. Slash-and-burn agriculture, which is the main component of households' livelihoods, is only permitted on dedicated fallows within a VOI's territory after the payment of the slashand-burn agriculture or tavy fee (Antona et al. 2004, Hockley and Andriamarovololona 2007). Therefore, the REDD+ project entails strict (for undisturbed forests) or fee-mediated (for degraded areas) restriction for the use of significant areas that were traditionally used for tavy. Such conservation restriction rules are likely to entail a cost for local communities, since farmers can no longer clear forest to manage soil fertility (Styger et al. 2009).

In addition to management transfers, REDD+ projects can fund local development projects which are expected to compensate and help households adapt to the losses arising from conservation restrictions. Recent studies have shown that these development projects faced the typical difficulties of Integrated Conservation and Development Projects (ICDPS), which are related to (i) elite capture, (ii) exclusion of the most vulnerable households, (iii) concentration of support on the more accessible zones, and (iv) inadequacy of the means proposed compared to the needs (Brimont et al. 2015). Therefore, households living in the territories affected by REDD+ projects are de facto hardly compensated for the agricultural and livelihood losses resulting from conservation restrictions.

Some authors argue that individual direct transfers benefit local populations more than ICDPS (Ferraro and Kiss 2002). Some one-off cases have been tested in Madagascar with relative success (Sommerville et al. 2010). Other academics argue that compensation covering only the cost of losing access to forest land is not sufficient to decrease deforestation over the long term, mainly because it does not address the drivers of deforestation. Such compensation should be linked to development activities that support agronomic innovation or the creation of economic alternatives (Karsenty 2011, Brimont and Karsenty 2015). Lack of financial means is a recurring problem for environmental NGOs and tropical conservation, and the gap between current funding and
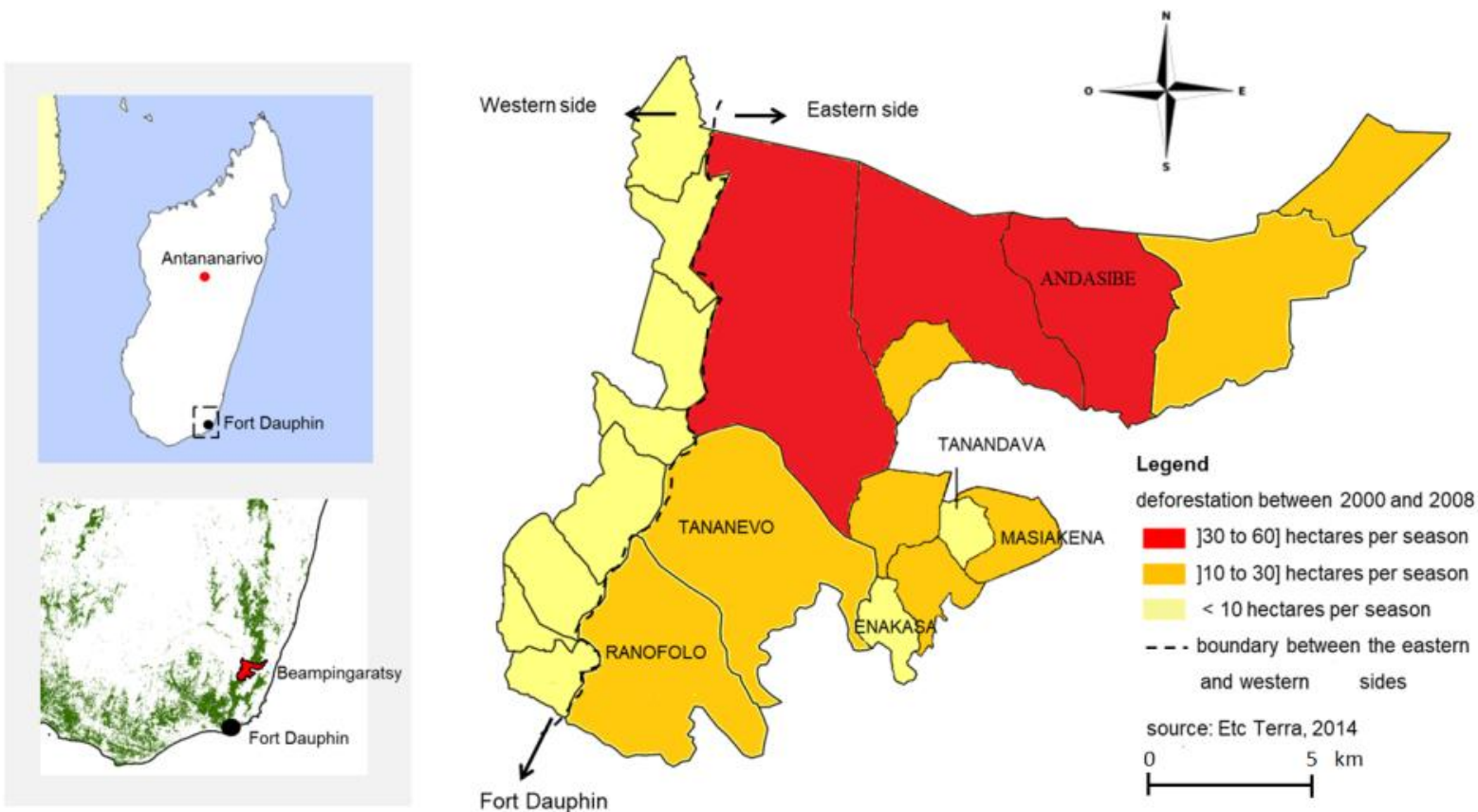

Figure 1. Study area with boundaries of the six participating VOIs. 
budget needs is particularly large in very poor countries like Madagascar (Balmford and Whitten 2003). The purpose of this paper is therefore to discuss whether a direct payment scheme-in cash or in kind-would be an economically and socially viable option as part of the ongoing Beampingaratsy REDD+ pilot project, in southeastern Madagascar, by assessing the cost of its implementation. Although no direct conditional transfers are currently being implemented in our study area, we ask whether the implementation of an individual compensation scheme in parallel with existing conservation and development activities appears to be an economically viable and efficient option.

THE BEAMPINGARATSY FOREST AND THE REDD+ CONSERVATION PROJECT. The Beampingaratsy forest covers 38,250 hectares and is located 100 kilometres north of FortDauphin, the largest town on the southeastern coast of Madagascar (Figure 1). More than 6500 households, i.e., about 30,000 people, live in this area (WWF 2011). The main driver of deforestation is tavy and the conversions of forest to pastureland on the western side of Beampingaratsy forest, while forest degradation is caused by collecting firewood (Laboratoire de Recherche Appliquée and WWF 2011).

The Beampingaratsy project started in 2009 as part of a nationwide REDD+ project called the Holistic Conservation Programme for Forests in Madagascar (HCPF), implemented by a French environmental association, Etc Terra (previously known as GoodPlanet), in partnership with the World Wide Fund for Nature (WWF). The project was funded by Air France, a French airline company. During the first implementation phase (2009-2012), the purpose of the HCPF REDD+ project was twofold: first, developing national carbon accounting methodologies to measure the reduction of emissions from deforestation and, secondly, implementing conservation activities in five forest areas of Madagascar, including Beampingaratsy. The overall budget of the Beampingaratsy project was about $\$$ US 150,000 (HCPF in litt., non-public accounting document). Functioning costs (salaries and office cost) amounted to $35 \%$ of the budget, while field activities accounted for $65 \%$. During this first period, the project supported the implementation of 20 management transfers (VOIs) and initiated the legal and administrative process to create the protected area. While in other REDD+ projects VOI territories are mainly located in the buffer zones of protected areas, in Beampingaratsy the future protected area was made up of the conservation zones of VOIs (Figure 2). This was due to both the specific topographical and demographic conditions of the Beampingaratsy forest, and the social-ecological purpose of the protected area: Beampingaratsy was intended to be an IUCN category $V$ protected landscape (IUCN 2016) where the interaction of people and nature is recognized and to be safeguarded. At the end of the first implementation phase, the project in the created Vols fostered a variety of development and conservation activities, which consisted of a re-



Figure 2. Zoning scheme of the Beampingaratsy REDD+ project. forestation programme, support for improving agricultural yield, such as training in improved rice growing techniques, and activities aimed at diversifying household incomes, i.e., beekeeping, cash crops, tree nurseries or market gardening. The project also funded a literacy programme for adults, which was implemented in some VOIs. The second implementation phase (2013-2017) is pursuing those development and conservation activities.

During the first implementation phase, the deforestation rate decreased from an average of $1.44 \%$ per tavy season before the project began (2000-2008), to $0.81 \%$ per tavy season (C. Grinand 2013 , pers. comm.). To provide a baseline for comparison, the deforestation rate at national level between 2000 and 2010 was 0.97\% (Mayaux et al. 2013).

PAYMENTS FOR ENVIRONMENTAL SERVICES (PES). The payments for environmental services (PES) literature usually distinguishes between three types of costs: (i) opportunity costs, i.e., households' forgone revenues from the protection of ecosystems, (ii) transaction costs, which cover the start-up and running costs incurred by the implementation and functioning of PES, and (iii) the actual payments (Pirard 2012, Ezzine-de-Blas et al. 2016). Many studies have evaluated the opportunity costs of reducing deforestation (for Madagascar case studies, see Kramer et al. 1995, Shyamsundar and Kramer 1996, Kremen et al. 2000, Ferraro 2002), and the transaction costs of direct incentive schemes in tropical countries (Angelsen 2008, Börner and Wunder 2008, Grieg-Gran 2008, Wunder et al. 2008).

\section{METHODS}

In this article, we differentiate costs according to their economic (opportunity vs. transaction costs), and time-dependent (start-up vs. running costs) rationales. We identify three categories of costs: compensation costs, implementation costs, and operating and monitoring costs.

Compensation costs: Compensation costs are the losses experienced by local populations resulting from conservation restrictions. As previously explained, in Madagascar conservation restrictions usually entail a decrease in agricultural production because farmers can no longer clear primary forest to manage soil fertility. Previous research in Madagascar studying the costs of conservation for local populations has not assessed the impacts on livelihoods; it has used either a contingent valuation approach, such as the "willingness-to-accept" methodology (Kramer et al. 1995, Shyamsundar and Kramer 1996, Desbureaux and Brimont 2015), or the opportunity costs method, in which the authors assess the potential income derived from practising agriculture on newly deforested land (Kremen et al. 2000, Ferraro 2002). For the purpose of this article, we chose to estimate the loss of household income arising from the implementation of the Beampingaratsy REDD+ project, i.e., restrictions on the use of natural resources established by VOI management plans, as a way of estimating the de facto real conservation cost for local populations. In order to estimate these costs, we conducted two series of semi-structured interviews with the heads of household located in the VOIs on the eastern side of the Beampingaratsy forest at the end of 2011 and mid-2012. This research covered six out of 12 Vols, representing 32,516 hectares of forest (Figure 2). In all, 100 households were interviewed. Because of the lack of any population census, we selected the householders who were at home when we visited the VOIs and who were willing to respond 
to our questions. To minimize sampling bias due to this constraint we visited 12 hamlets located in the buffer zone of the protected forest. The vols had been informed of our arrival prior to a meeting with local authorities on the weekly market day.

We used two proxies to measure the impact of the project on livelihoods: The change in the reported time allocated to the different agricultural activities of the household, and the change in the reported production associated with each of the agricultural activities. Changes in time were measured using the pebble distribution method developed by Colfer, Sheil and coworkers (Colfer et al. 1999, Sheil et al. 2001, sheil et al. 2003). The pebble distribution method is a scoring procedure based on pictures which symbolize the outcomes to be scored: the counters should be attributed to outcomes according to their quantitative relationships or values. The participants are then asked to explain the final scores (Lynam et al. 2007). The pebble distribution method is appropriate in very poor areas where people are often illiterate. Pictures and physical counters help them to represent trends and serve as a basis for the discussion. As agricultural activities are likely to be impacted by conservation restrictions, we identified the different crops grown by farmers with the help of the project staff. We drew cards to represent each crop using two colours, one representing crops grown inside the forest, and the other crops grown outside the forest.

Tubers (cassava, yams, sweet potatoes) and rainfed rice were found to be the main crops in forest; fruits (banana, pineapple), coffee, tobacco and sugarcane were also grown in fields mixed with forest regeneration. In non-forest areas, irrigated rice was the main crop, with cassava and other semi-perennial tubers. There were also perennial crops such as fruit trees (litchi, mango or orange trees) mainly used for home consumption, and cash crop trees (coffee).

The interviews proceeded in two steps. First, participants were asked to distribute counters according to the time they had allocated to different crops before the project started, i.e. in 2008. We converted counters into an actual share of time by dividing the number of counters allocated to each crop by the total number of counters used (participants were free to choose the global quantity of counters they wanted to). Secondly, we asked for the quantity of production associated with each crop. For this step the counters were used as a basis for discussing agricultural production. We converted agricultural production into monetary equivalent using local market prices to calculate the income derived from each crop. We classed incomes in five groups: (i) perennial crops grown in the forest, (ii) annual crops grown in the forest, (iii) per-

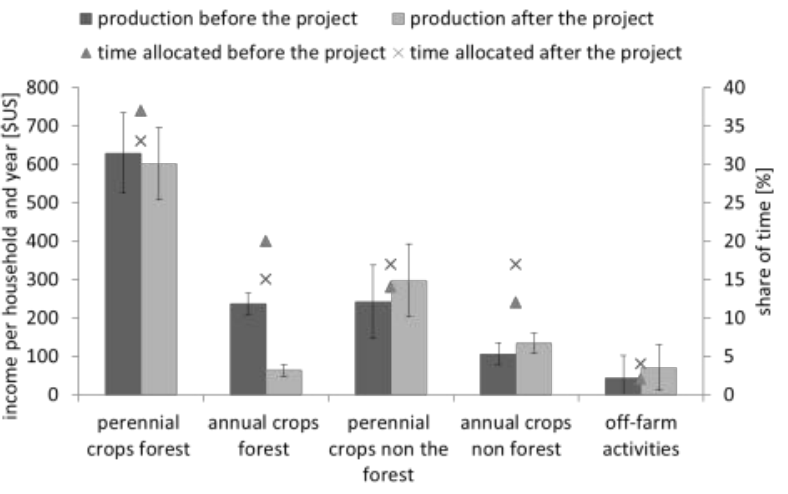

Figure 3. Changes in production value before and after implementation of the project in the affected and unaffected households ( $N=100$, error bars indicate standard errors). ennial crops grown outside the forest, (iv) annual crops grown outside the forest, and ( $v$ ) off-farm activities.

We repeated the same procedure for 2011. If changes had taken place between 2008 and 2011, we investigated causal relationships through semi-structured discussions with the participants to capture the net effect of the implementation of the protected area. We validated our identification of the households who had been affected by the implementation of the protected area with a census carried out by the team of the project that had identified the households most reliant on forest land. To estimate the net cost borne by the households affected by the project, we compared the stated changes in agricultural production between 2008 and 2011 for the two groups of households. Changes in production were calculated by subtracting production in 2008, i.e., before the implementation of the project, from production in 2011 for each household, i.e., after the implementation of the project (Figure 3). A positive income meant that production increased from 2008 to 2011, while a negative income meant production decreased from 2008 to 2011. In addition to crop cards, we added a card representing off-farm activities (small-scale mining, self-retailing, building work, basketry) and agricultural employment to measure the changes in time and income associated with offfarm activities. We also collected data on the main characteristics of the households we interviewed (e.g., family composition, age and level of education and origin of the head of family). Parametric statistics (Student's t-test) were performed with $\mathrm{R}$ software.

Operating and monitoring costs: Operating and monitoring costs were running transaction costs. We assumed that the direct payment scheme would be implemented in parallel with existing conservation and development activities while human resources remained constant. Our estimations referred to the costs incurred by implementing the individual compensation scheme only. Operating costs covered management costs which are administrative costs including the transportation and distribution of the compensation. As there are no bank services around the Beampingaratsy forests, we further assumed that the person in charge of the VOls would go to the nearest town, Fort Dauphin, obtain the money, and then distribute it to the beneficiaries (one distribution event per year). Operating costs included (i) the commission of the bank in charge of the money deposit, and (ii) the transport, accommodation and expenses of people in charge of money withdrawal and distribution. The bank commission was estimated based on a former programme of direct payments to VOIs implemented by Conservation International (Cl) in Didy, a rural town on the edge of the CAZ protected area (Ankeniheny-Zahamena Corridor). In this programme, the money was managed by a micro-credit institution which took a $2.5 \%$ commission. The other operating costs as well as monitoring costs were estimated using data from the accounting documents of the Beampingaratsy project at WWF regional office in Fort Dauphin. Monitoring would be undertaken on a yearly basis by the NGO in charge of project implementation to confirm that the compensation was distributed to each beneficiary, and collect forest and socio-economic data to assess changes.

Implementation costs: Implementation costs were one-off transaction costs which occurred before the start of the payments. They were composed of two activities: the identification of beneficiaries and the information and awareness campaign. The identification of beneficiaries, i.e., the households who were affected by the conservation project, would be done by Malagasy 
consultants living in the Fort Dauphin area (meaning low transportation costs). We estimated these costs based on the accounting documents of the Beampingaratsy project. After identifying the beneficiaries, the implementer staff would explain the purpose of the compensation programme and present the criteria used to select the beneficiaries of the compensation. Beneficiary identification cards-which helped to identify beneficiaries as identity cards are uncommon in that place-were distributed to each individual beneficiary to inform him/her of his/her right to receive the compensation.

\section{RESULTS}

COSTS FOR LOCAL HOUSEHOLDS. Considering both changes

in time allocation and in incomes, our results showed that 38 out of a total of 100 heads of household had not perceived any change in their activities, 47 stated a negative impact in their activities due to the implementation of the protected area, and 11 stated changes due to causes other than the implementation of the protected area, such as climate events, health problems, insect pests, etc. Lastly, four households reported positive changes due to the implementation of the conservation project. These farmers grew irrigated rice in the bottomlands, and they said that forest conservation had increased the water supply for their fields and improved their yields. These statements should be treated with caution, as a positive impact due to a reduction in deforestation on the water supply is yet to be confirmed and would, if such a causal relationship were to be confirmed, require time to happen (R. Vaudry 2014, pers. comm.). Instead, these perceptions can be interpreted as echoing the NGO's environmental discourse

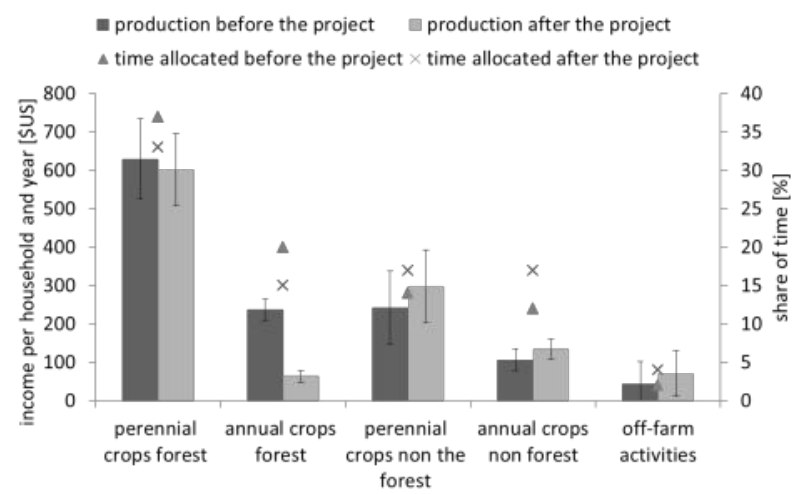

Figure 4. Perceived changes in agricultural production value (bars) and in share of time for different farming activities for affected households ( $\mathrm{N}=47$, error bars indicate standard errors).

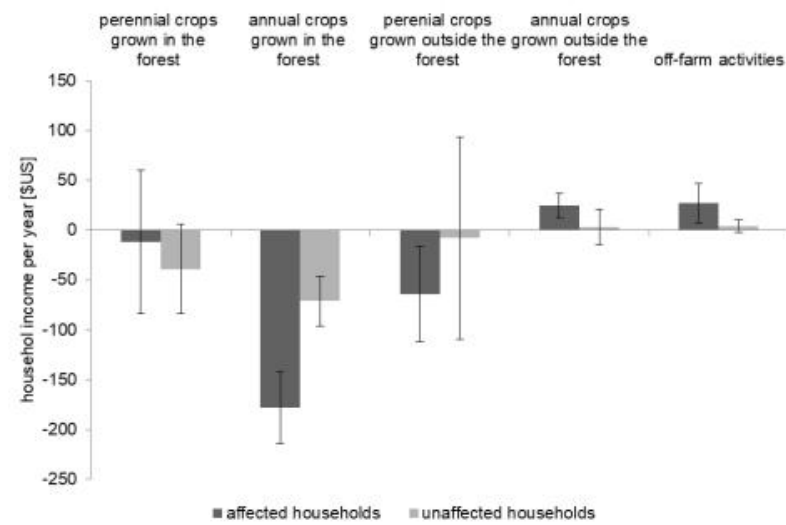

Figure 5. Perceived changes in agricultural production value (bars) and in share of time for households having stated no impact $(\mathrm{N}=53$, error bars indicate standard errors). about the link between water and forests. The 47 households who considered the changes in their activities due to the conservation project to be negative, henceforth referred to as the 'affected households' as opposed to the other 53 households, called 'unaffected households', mentioned decreasing yields as the main reason, since they were not allowed to clear undisturbed forest to access new fertile land for tavy activities. In order to adapt to this constraint, these farmers had to clear former fallow areas where fertility had been already exhausted. As a result, farmers chose to stop growing some of the crops usually grown in the forest-mainly rice- either because yield was too low, or because they preferred to set aside the land outside the forest in order to allow soil fertility to recover. Dependence on forests for this group of households appeared to be substantial (Figure 4) compared to unaffected households (Figure 5). These results showed that land use restrictions affected in particular the households who relied most on slash-and-burn agriculture.

We observed a significant decrease in the production of annual crops farmed on forest land by both affected and unaffected households. The average income from crops grown on forest land by affected households dropped from \$US 238/yr to \$US 64/yr (ttest, $p=0.0001$ ) and by unaffected households from $\$$ US 103/yr to $\$$ US 36/yr (t-test, $p=0.04$ ). This means that factors other than the conservation project impacted agricultural production homogeneously for both unaffected and affected households. According to our respondents, these factors were climate events, health problems of the head of household and insect pests. Conservation restrictions exacerbated such drops, since the decrease in agricultural production of the affected households was statistically greater than that of the unaffected households. The decrease in time allocation for annual forest crops fell from $20 \%$ to $15 \%$ for the affected households (t-test, $p=0.05$ ); this was not the case for unaffected households ( $t$-test, $p=0.21$ ). The time devoted by affected households to annual non-forest crops, i.e., irrigated rice, increased from $12 \%$ to $17 \%$ (t-test, $p=0.02$ ), whereas it remained stable for the unaffected households ( $24 \%$ before the project and $23 \%$ after).

The difference between the affected and unaffected groups was only statistically significant for the annual crops in the forest. Affected households lost an average of \$US 178/yr while unaffected households lost $\$$ US 71/yr (t-test, $\mathrm{p}=0.02$ ); net losses due to the implementation of the conservation project were \$US 107/yr per affected household. This loss amounted to around $11 \%$ of the average monetary equivalent of the total agricultural production per household.

DIRECT COMPENSATION SCHEME. In order to extrapolate such a figure to the overall east-side project implementation zone, we estimated $55 \%$ of households whose agricultural production had been affected by the project $(55 \%$ is the average of our own estimation and the estimation of the census made by the project team to identify the households most reliant on forest land as previously mentioned). Thus, out of a total of 4400 households on the eastern side of Beampingaratsy some 2420 households were assumed to have been affected by the project. The overall economic agricultural cost experienced by forest populations on the eastern side of Beampingaratsy thus amounted to \$US 258,940 per year.

Implementation costs included (i) the identification of beneficiaries among some 4400 households, and (ii) the information and 
awareness campaign to inform beneficiaries of their right to receive the compensation. Identification of the beneficiaries would require a field survey. Assuming that a survey carried out 4 interviews per day, the survey needed 1100 man-days paid at \$US 30 per day $(80,000$ ariary). We added $\$$ US 3000 for transport (from Fort Dauphin) and equipment (camping gear, paper forms, etc.), and we calculated that the total cost of the field survey would amount to \$US 39,000 (including \$US 3,000 for the design of the survey and the database).

We budgeted \$US 7750 for data processing, i.e., computerization (220 man-days paid at \$US 30) and the analysis of the database to draw up a list of selected beneficiaries (30 man-days paid at \$US 30). We budgeted \$US 2000 for the creation of beneficiary cards, and \$US 2500 to organize a session to report back the results to local authorities, the people in charge of the Vols, and the local population.

Operating costs covered compensation money management and annual withdrawal: We assumed that the bank commission would be $2.5 \%$ of the total deposit (\$US 258,940 ), i.e., $\$$ US 6475 . Regarding the cost of the withdrawal of money by the people in charge of the VOIs, we budgeted \$US 80 per VOI per year for transport, accommodation and per diem i.e., \$US 960 per year for all the VOIs. Monitoring costs covered the annual field survey made by the implementer staff to check that compensation had been distributed to each beneficiary, and collect forest and socioeconomic data to assess changes. The cost of the annual field survey was the same as the initial field survey, which explains why the operating and monitoring costs were very similar to the implementation costs.

The estimated total cost of implementing direct compensation scheme to the households affected by the implementation of the project was $\$$ US 361,375 for the first year, and \$US 310,125 in subsequent years. Related to the size of forest in VOls located on the eastern side of the Beampingaratsy forest (32,516 hectares), the cost was around \$US 11 per hectare the first year, and around \$US 10 per hectare per year the subsequent years. Related to the number of households in these VOIs (4400 households), the cost was around \$US 82 per household the first year, and \$US 70 per household per year the subsequent years. If we added to our estimation the current operating budget of the project ( $\$$ US 150,000 during the first implementation phase, i.e., \$US 50,000 per year), the overall cost amounted to \$US 411,375 the first year, and \$US 360,125 in subsequent years (Tables 2 and 3). Related to the size of the forest in the study zone $(32,516$ hectares), the cost was around \$US 13 per hectare the first year, and around \$US 11 per hectare per year the subsequent years. Related to the number of households living in this area (4400 households), the cost was around \$US 93 per household the first year, and \$US 82 per household for the subsequent years.

\section{DISCUSSION}

This paper estimated the overall cost of implementing an individual compensation scheme as part of a REDD+ project in Madagascar. Assessing the impact of conservation restrictions on forest land use on local livelihoods, we found that about half of the 4400 households in the study area were affected by the project. The average loss was $\$$ US 107 per household per year, which amounted to about $11 \%$ of the average monetary equivalent of the total agricultural production per household. Our results showed that the time devoted by affected households to irrigated rice increased from $12 \%$ to $17 \%$ : the conservation project probably incited the affected households to reallocate their time from slash-and-burn agriculture to the cultivation of irrigated rice. However, we did not detect a statistically significant simultaneous increase in production for any of the two groups. This result might respond to two (non-exclusive) factors; first, the increase in labour input was too

Table 1. Yearly costs of implementing a direct compensation scheme.

\begin{tabular}{llc} 
Categories of costs & Details & Detailed budget [in \$US] Aggregate budget [in \$US] \\
\hline Compensation costs & \$US107 per household (2,420 households) & 258,940 \\
& Methodology and database design & 3000 \\
& Field survey & 36,000 \\
Implementation costs (only the first year) & Survey analysis & 7750 \\
& Beneficiaries' identification cards & 2000 \\
& Reporting and distribution of beneficiaries' cards & 2500 \\
& Sub-total & 6475 \\
\hline & Bank fees (in Fort Dauphin) & 960 \\
Functioning and monitoring costs & Cash withdrawal & 36,000 \\
& Field survey & 7750 \\
\hline Total for the first year & Survey analysis & 51,250 \\
\hline Total for subsequent years & Sub-total & 51,185 \\
(without implementation costs) & & 361,375 \\
\hline
\end{tabular}

Table 2. Summary of the cost estimates.

\begin{tabular}{|c|c|c|c|c|}
\hline \multirow{4}{*}{ Direct payments scheme } & & Total per year [\$US] & Per hectare per year [\$US] & Per household per year [\$US] \\
\hline & Opportunity costs & 258,940 & 8 & 59 \\
\hline & Transaction costs (first year) & 102,435 & 3 & 23 \\
\hline & Transaction costs (subsequent years) & 51,185 & 2 & 12 \\
\hline \multicolumn{2}{|c|}{ Subtotal (first year) } & 361,375 & 11 & 82 \\
\hline \multicolumn{2}{|c|}{ Subtotal (subsequent years) } & 310,125 & 10 & 70 \\
\hline \multirow[t]{2}{*}{ Current operating budget } & Investment costs & 32,500 & 1 & 7 \\
\hline & Transaction costs & 17,500 & 1 & 4 \\
\hline \multicolumn{2}{|c|}{ Subtotal } & 50,000 & 2 & 11 \\
\hline \multicolumn{2}{|c|}{ Total (first year) } & 411,375 & 13 & 93 \\
\hline \multicolumn{2}{|c|}{ Total (subsequent year) } & 360,125 & 11 & 82 \\
\hline
\end{tabular}


small to be translated into higher production, particularly given that initiating irrigated agriculture requires a significant amount of work to build terraces and level the land-it then gradually requires less work and yields higher production-and second, inputs other than labour were required to improve agricultural yield, including soil fertility and agricultural techniques.

We then estimated the transaction costs of implementing a direct compensation scheme, and we obtained an overall cost of \$US 361,375 for the first year and \$US 310,125 in subsequent years because of start-up costs. Transaction costs accounted for a substantial share of the cost of implementing a PES scheme, a finding that was in line with what some other authors have highlighted (e.g., Norgaard 2010, Pirard 2012). Our study showed that transaction costs made up $29 \%$ of the overall costs the first year and $19 \%$ the subsequent years. The cost of compensating affected households was high compared to the current funding levels of the REDD+ project. The current budget devoted to field activities (e.g., community-based natural resource management, development activities, tree planting) in the eastern part of Beampingaratsy was about $\$$ US 50,000 in the last budgeted year of the project, which is more than seven times less than the budget required for implementing the compensation scheme. This article therefore confirms that compensating local populations entails significant costs, especially when poor populations (i.e., with a low opportunity cost) are concerned.

Funding tropical conservation has been difficult for many years, and the current financial crisis in industrialized countries has worsened it. The possibility of funding from the carbon voluntary market and the REDD+ mechanism was tangible at the time the project was conceived and its implementation started, but currently the voluntary carbon market is saturated, many projects are unable to sell their carbon credits, and REDD+ projects on a local scale are no longer supported by institutional donors such as the World Bank, which supports 'jurisdictional' programmes on a much larger scale (Seyller et al 2016). Balmford and Whitten (2003) concluded that the lack of funding was mainly due to political interests. This still holds true when we consider the amounts of money spent on REDD+ readiness programmes (expertise, workshops, negotiations, etc.) and the tiny share that actually goes to local populations (Bidaud 2012). Regarding the REDD+ national strategy, the budget estimated for Madagascar was \$US 7.378 million, of which 65\% was for scientific activities, such as carbon stock measurement (FCPF 2013). It is to be hoped that the financial commitments made by developed countries at the last Conference of the Parties (COP21) in Paris for mitigation and adaptation to climate change-\$US 100 billion are expected for developing countries by 2020 to implement action for mitigation and adaptation to climate change-will breathe new life into the funding of conservation and development field activities.

Aside from the financial constraints, other factors may explain why some conservation NGOs and the Government of Madagascar do not implement direct compensation. First, legal arguments can be mentioned, as farmers have long been compelled by law to stop slash-and-burn agriculture in primary forest. During a research meeting at the University of Antananarivo in 2012, an NGO representative replied to criticisms about the absence of compensation for the costs borne by local peasants saying that NGOs and the State are not obliged to pay compensation for stopping primary forest clearance as it is in any case against the law. This means the customary rights of local populations on natural resources are not actually recognized in spite of the management transfers. Second, we cannot exclude the possibility that compensating households can create perverse effects, especially by attracting new migrants from neighbouring areas (even though the control of new migration can be part of the PES contracts proposed to communities). Other consequences may be related to the nature of the compensation. Compensating with cash can entail a loss of intrinsic motivation, rendering future conservation actions more expensive and difficult to fit in with the local population. Aligning in-kind compensation with local motivation might be a strategy for minimizing such risks (Rode et al., 2015). Third, in a context of limited financial means and uncertainty about the future of carbon funding, conservation NGOs may prefer to concentrate their money on development activities rather than combining them with direct compensation, in the hope that benefits from investments in rural development would continue even after the project ends.

Our study showed that the perceived changes in livelihoods from conservation restrictions pointed in the direction of a major disruption to the local populations' agricultural subsistence practices. Aware of such a situation, and after numerous exchanges with the authors of this study, Etc Terra decided to increase the project's investment in agricultural innovation to improve irrigated rice yields through better growing techniques, slash-and-burn fertility improvement through agro-ecological techniques, and support for the development of cash crops (Etc Terra 2015). Such a turn in the REDD+ project implementation strategy is in line with the numerous informal discussions we had with local farmers on their need for agricultural support, in particular for the construction and maintenance of water infrastructure for irrigated rice. By implementing individual compensation until the new agricultural systems become operational and in parallel with agricultural investments, affected households would more likely experiment with innovative techniques and increase the project take-up and overall legitimacy. Individual compensation would thus be part of a mix of conservation and development instruments including protected areas, management transfers and agricultural investments. They may play the role of safety nets and help farmers, especially the most vulnerable ones, to test innovative agricultural techniques.

In this paper we adapted the pebbles distribution method to capture households' declarative statements about the changes in their agricultural production before and after the project. This method was based on reconstructed and stated data, and was therefore sensitive to the interviewee's subjectivity. Nevertheless, the pebble distribution method has proved reliable in numerous research activities to capture consistent data trends (Colfer et al. 1999, Sheil et al. 2001, Sheil et al. 2003). A systematic flaw in the reported perceptions would have prevented our analysis from capturing statistically significant differences between affected and unaffected households. In addition, we confirmed our categorization between affected and unaffected households by doublechecking with the WWF local team household field census. Lastly, our estimated economic compensation provided the most up-todate figures when compared to available studies: Shyamsundar and Kramer (1996) found that households would accept 185 kilograms of rice per year to stop using forest located within the conservation zone of the Mantadia protected area, while in our case study, \$US 107 amounted to $284 \mathrm{~kg}$ of rice, and Ferraro (2002) estimated that stopping deforestation costs would range from \$US 
59 to 216 per household and per year in the Ranomafana corridor (we updated Ferraro's estimate taking into account the inflation rate since 2002 (INSTAT 2015)).

Individual compensation would be part of a mix of conservation and development instruments to increase both the long-term environmental and social efficacy of the REDD+ projects in Madagascar. They could also increase the legitimacy of the projects, on local, national, and even international scales. Much criticism has surfaced in Madagascar and abroad since the Government decision to increase the size of the protected area network: conservation NGOS are blamed for "economically displacing" some of the poorest people on the planet. The Madagascar Environmental Justice Network is representative of this movement which brings together scholars, activists and professionals to denounce the social impacts of the natural resources policy in Madagascar ${ }^{1}$. By adequately compensating the local population, individual compensation may facilitate the political acceptance of conservation policies.

\section{ACKNOWLEDGEMENTS}

The authors are very grateful to the HCPF project team in Madagascar and France for their collaboration and for sharing resources. We thank Romuald Vaudry (EtcTerra) for his informed contributions to this paper. We also thank Patricia Rahantamalala, Christian Ratianarivo, and Xavier Visseq for their valuable help in data collection. We thank the ISIS programme for providing SPOT images at a preferential rate to analyse deforestation trends in the Beampingaratsy area, and Clovis Grinand (EtcTerra) for his contribution in analysing the deforestation data. This study was part of the PESMIX research programme (Payments for environmental services: new panacea or auxiliary for environmental management?) funded by the French Research Agency (ANR). This project received financial support from the French government under the "Investissements d'avenir" programme, managed by ANR under the reference ANR-10-LABX-01. We also thank the reviewers of MCD for helping to improve this manuscript.

\section{REFERENCES}

Angelsen, A. 2008. Moving Ahead with REDD: Issues, Options and Implications. Center for International Forestry Research (CIFOR), Bogor. Available at $<$ http://www.cifor.org/library/2601/moving-ahead-with-redd-issues-optionsand-implications/>

Antona, M., Motte-Biénabe, E., Salles, J.-M. and Péchard, G. 2004. Rights transfers in Madagascar biodiversity policies: achievements and significance. Environment and Development Economics 9, 6: 825-847. (doi:10.1017/S1355770X04001640)

Balmford, A. and Whitten, T. 2003. Who should pay for tropical conservation, and how could the costs be met? Oryx 37, 2: 238-250. (doi:10.1017/S0030605303000413)

Bidaud, C. 2012. REDD+, un mécanisme novateur ? Le cas de la forêt de Makira à Madagascar. Revue Tiers Monde 211: 111-130. (doi:10.3917/rtm.211.0111)

Börner, J. and Wunder, S. 2008. Paying for avoided deforestation in the Brazilian Amazon: from cost assessment to scheme design. International Forestry Review 10, 3: 496-511. (doi:10.1505/ifor.10.3.496)

Brimont, L., Ezzine-de-Blas, D., Karsenty, A. and Toulon, A. 2015. Achieving conservation and equity amidst extreme poverty and climate risk: the Makira REDD+ Project in Madagascar. Forests 6, 3: 748-768. (doi:10.3390/f6030748)

Brimont, L. and Karsenty, A. 2015. Between incentives and coercion: the thwarted implementation of PES schemes in Madagascar's dense forests. Ecosystem Services 14:113-121. (doi:10.1016/j.ecoser.2015.04.003)
Colfer, C. J. P., Brocklesby, M. A., Diaw, C., Etuge, P., Günter, M., et al. 1999. The Grab Bag: Supplementary Methods for Assessing Human Well-being. Center for International Forestry Research (CIFOR), Bogor, Indonesia. (doi:10.17528/cifor/000766)

Corson, C. 2011. From rhetoric to practice: How high-profile politics impeded community consultation in Madagascar's new protected areas. Society \& Natural Resources 25, 4: 336-351. (doi:10.1080/08941920.2011.565454)

Desbureaux, S. and Brimont, L. 2015. Between economic loss and social identity: The multi-dimensional cost of avoiding deforestation in eastern Madagascar. Ecological Economics 118: 10-20. (doi:10.1016/j.ecolecon.2015.07.002)

Etc Terra. 2015. <http://www.etcterra.org/fr/projets/phcf/phcf2> accessed 5 January 2016.

Ezzine-de-Blas, D., Hrabanski, M. and Le Coq, J. F. 2015. Les paiements pour services environnementaux dans les politiques de changement climatique. In: Changement Climatique et Agricultures du Monde. E. Torquebiau (ed.), pp 257-267. Quæ, Versailles, France.

Ezzine-de-Blas, D., Wunder, S., Ruiz-Pérez, M. and Moreno-Sanchez, R. del P. 2016 Global patterns in the implementation of payments for environmental services. PLOS ONE 11, 3: e0149847. (doi:10.1371/journal.pone.0149847)

FCPF (The Forest Carbon Partnership Facility). 2013. Proposition des Mesures pour l'Etat de Préparation-Madagascar (R-PP). World Bank, Antananarivo. Available at <https://www.forestcarbonpartnership.org/madagascar>

Ferraro, P. J. 2002. The local costs of establishing protected areas in low-income nations: Ranomafana National Park, Madagascar. Ecological Economics 43, 2-3: 261-275. (doi:10.1016/S0921-8009(02)00219-7)

Ferraro, P. J. and Kiss, A. 2002. Direct payments to conserve biodiversity. Science 298: 1718-1719. (doi:10.1126/science.1078104)

Grieg-Gran, M. 2008. The Cost of Avoiding Deforestation. Update of the Report prepared for the Stern Review of the Economics of Climate Change. International Institute for Environment and Development (IIED), London. Available at <http://pubs.iied.org/G02489/>

Hockley, N. J. and Andriamarovololona, M. M. 2007. The Economics of Community Forest Management in Madagascar: Is There a Free Lunch? An Analysis of Transfert de Gestion. United States Agency for International Development (USAID), Washington, D.C. Available at <http://pdf.usaid.gov/pdf_docs/Pnadl290.pdf>

INSTAT. 2015. <<http://instat.mg/actualites/taux-inflation-madagascar/> accessed on 25 January 2015.

IPCC (Intergouvernmental Panel on Climate Change). 2007. Fourth Assessment Report: Climate Change 2007. Synthesis Report. Intergovernmental Panel on Climate Change, Geneva. Available at <goo.gl/8AZHtL>

IUCN. 2016. Protected Areas Categories. Available at $<$ https://www.lucn.org/theme/protected-areas/about/protected-areas-categories>

Karsenty, A. 2011. Payments for environmental services and development: Combining conservation incentives with investment. Perspective \#7. Available at $<$ g00.gl/WQ0060>

Karsenty, A. and Ongolo, S. 2012. Can "fragile states" decide to reduce their defor estation? The inappropriate use of the theory of incentives with respect to the REDD mechanism. Forest Policy and Economics 18: 38-45. (doi:10.1016/j.forpol.2011.05.006)

Kramer, R. A., Sharma, N. and Munasinghe, M. 1995. Valuing Tropical Forests: Methodology and Case Study of Madagascar. World Bank, Washington D.C. Available at $<$ http://documents.worldbank.org/curated/en/141111468777013173/pdf/multi-page.pdf>

Kremen, C., Niles, J. O., Dalton, M. G., Daily, G. C., Ehrlich, P. R. et al. 2000. Economic incentives for rain forest conservation across scales. Science 288 1828-1832. (doi:10.1126/science.288.5472.1828)

Laboratoire de Recherches Appliquées (LRA) and WWF2. 2011. Analyse des agents et facteurs de déforestation et identification des zones des fuites du projet HCPF à partir de la cartographie participative. Rapport final, Antananarivo. 
Lynam, T., De Jong, W., Sheil, D., Kusumanto, T. and Evans, K. 2007. A review of tools for incorporating community knowledge, preferences, and values into decision making in natural resources management. Ecology and Society 12 , 1: 5. Available at <http://www.ecologyandsociety.org/vol12/iss1/art5/>

Mayaux, P., Pekel, J.-F., Declée, B., Donnay, F., Lupi, A. et al. 2013. State and evolution of the African rainforests between 1990 and 2010. Philosophical Transactions of the Royal Society B 368, 1625: \#20120300. (doi:10.1098/rstb.2012.0300)

Norgaard, R. B. 2010. Ecosystem services : From eye-opening metaphor to complexity blinder. Ecological Economics 69, 6: 1219-1227. (doi:10.1016/j.ecolecon.2009.11.009)

O'Connor, D. 2008. Governing the global commons: Linking carbon sequestration and biodiversity conservation in tropical forests. Global Environmental Change 18, 3: 368-374. (doi:10.1016/j.gloenvcha.2008.07.012)

Pan, Y., Birdsey, R. A., Fang, J., Houghton, R., Kauppi, P. E., et al. 2011. A large and persistent carbon sink in the world's forests. Science 333: 988-993. (doi:10.1126/science.1201609)

Pirard, R. 2012. Market-based instruments for biodiversity and ecosystem services: A lexicon. Environmental Science \& Policy 19-20: 59-68. (doi:10.1016/j.envsci.2012.02.001)

Rode, J., Gómez-Baggethun, E. and Krause, T. 2015. Motivation crowding by economic incentives in conservation policy: A review of the empirical evidence. Ecological Economics 117: 270-282. (doi:10.1016/j.ecolecon.2014.11.019)

Seyller, C., Desbureaux, S., Ongolo, S., Karsenty, A., Simonet, G., et al. 2016. The "virtual economy" of REDD+ projects: does private certification of REDD+ projects ensure their environmental integrity? International Forestry Review 18, 2: 231-246. (doi:10.1505/146554816818966336)

Sheil, D., Puri, R. K., Basuki, I., van Heist, M., Saefuddin, et al. 2001. Exploring Biological Diversity, Environment and Local People's Perspectives in Forest Landscapes. Center for International Foresty Research (CIFOR), Ministry of Forestry, and International Tropical Timber Organization, Bogor, Indonesia.

Sheil, D., Liswanti, N., van Heist, M., Basuki, I., Syaefuddin, et al. 2003. Local Priorities and Biodiversity. ITTO Tropical Forest Update 13, 1: 16-18. Available at <http://www.cifor.org/library/1322/local-priorities-and-biodiversity/>

Sommerville, M., Jones, J. P. G., Rahajaharison, M. and Milner-Gulland, E. J. 2010. The role of fairness and benefit distribution in community-based Payment for Environmental Services interventions: A case study from Menabe, Madagascar. Ecological Economics 69, 6: 1262-1271. (doi:10.1016/j.ecolecon.2009.11.005)

Shyamsundar, P. and Kramer, R. A. 1996. Tropical forest protection: an empirical analysis of the costs borne by local people. Journal of Environmental Economics and Management 31, 2: 129-144. (doi:10.1006/jeem.1996.0036)

Styger, E., Fernandes, E. C. M., Rakotondramasy, H. M. and Rajaobelinirina, E. 2009. Degrading uplands in the rainforest region of Madagascar: Fallow biomass, nutrient stocks, and soil nutrient availability. Agroforestry Systems 77: 107-122. (doi:10.1007/s10457-009-9225-y)

Wunder, S., Engel, S. and Pagiola, S. 2008. Taking stock: A comparative analysis of payments for environmental services programs in developed and developing countries. Ecological Economics 65, 4: 834-852. (doi:10.1016/j.ecolecon.2008.03.010)

WWF2. 2011. Informations nécessaires sur la NAP de Beampingaratsy. Unpubl. report.

1 see for example <http://www.bastamag.net/Avec-Air-Francecompenser-les>

2 Please contact the authors for a pdf of these unpublished reports. 